\title{
地すべり対策工の効果推定における安定解析の不確定要素の影響 On the Influence of the Indefinite Elements of the Stability Analysis on Presumption of Effect of Landslide Countermeasures
}

\author{
榎田充哉*) \\ Mitsuya ENOKIDA
}

\begin{abstract}
The safety factor of 2-dimensional analysis used by countermeasure plan of a landslide serves as a value which included the error with various indefinite elements about the calculation error and stability analysis by the stability analysis formula to adopt. Although the error of asfety factor has influenced on effect presumption of countermeasure greatly, there is almost no verification example with the general-purpose but only with individual on-site example. On the other hand, though the designed safety factor in countermeasure plan is an important value which determines the scale of countermeasure, the validity of the value owes a lot to experience, and it is not verified scientifically yet. By verifying the influence of the indefinite element on effect of countermeasure generally, I think in the future, it will be also useful to verification of the validity of designed safety factor. In this paper, I took notice of 3 main indefinite elements, the unit weight of move layer, strength parameters of slip surface,slip surface depth. Then verified influence of these 3 elements on effect of couner measurements, groundwater drainage works, soil removal works, prevention works by using the 133 spot and 243 section of on-site data all over the country. I also verified about the superposition effect of the presumed error by two or more indefinite elements, or the presumed error by the difference in a stability analysis formula.

As $s$ result, it became clear change of effect presumption of countermeasure by the presumed error of indefinite elements becomes larger as a scale of landslide is small, the influence of the indefinite elements increases by using countermeasure together, and the landslides which's evaluation value of countermeasure effect using the Fellenius method are bigger than using the simple Janbu method are more than $60 \%$ of whole.

Keywords : landslide, stability analysis, designed safety factor, countermeasure

\section{和文要旨}

地すべりの対策工計画で利用される 2 次元安全率は採用する安定解析式による計算誤差や安定解析に関するさまざまな不確定要 素によって誤差を含んだ值となっている。この安全率の誤差が対策工の効果推定にも大きく影響しているが, 個別の現場事例につ いて検証した事例はあるものの汎用的な検証事例はほとんどない。

一方，対策工計画に抽計画安全率は対策工の規模を決定する重要な值であるが，その值の妥当性は経験的なものに負うとこ ろが大きく，学術的に検証されていない。対策工効果に与える不確定要素の影響を汎用的に検証することにより，今後，計画安全 率の妥当性の検証に役立つと考える。

本論では代表的な不確定要素として移動層の単位体積重量, すべり面の土質強度定数，すべり面深度の $3 つ に$ 注目し，地下水排 除工，排土工，抑止工の 3 つの対策工効果へのこれら不確定要素の影響を全国133現場243断面の現場事例デー夕を用いて検証した。 その中で複数の不確定要素による推定誤差の重ね合わせ効果や安定解析式の違いによる推定誤差についても検証した。

その結果, 不確定要素の推定誤差による対策工効果推定の変動は地すべりの規模が小さいほど大きくなること, 対策工を併用す ることによってその不確定要素の影響が増大すること，簡便法による対策工効果の評価値が簡易Janbu法による評価値より大きくな る地すべりが全体の 6 割以上になることなどが明かとなった。

キーワード：地すべり，安定解析，計画安全率，対策工
\end{abstract}

\section{1.はじめに}

地すべりの対策工計画では通常, 2次元の極限平衡法 (Limit Equilibrium Analysis) による安全率を用いて対 策工の効果を評価する。地すべりの現状安全率または初 期安全率を推定し, 計画安全率（目標安全率）を達成す るための対策工の組合せを検討して対策工計画が作成さ れる。この計画安全率の大きさは地すべりの規模や地す ベりによって被災するであろう保全対象の重要性などに よって決められるものであるが, 各種基準書にはその目 安として $F_{p}=1.10 \sim 1.20$ と記載されている。

地すべりの安全率 $F$ は $F>1.0$ であれば安定状態であ

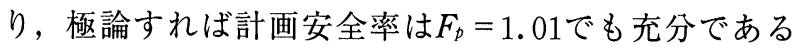
が，降雨や融雪などの誘因変量が予想を上回った場合の

*) 国土防災技術株式会社

テ336-0002 埼玉県さいたま市北浦和2-12-11
安全率の余裕を考慮する必要があることや，すべり面位 置などの地すべり形状の推定誤差，すべり面に作用する 間隙水圧分布の推定誤差, すべり面粘土のせん断強度な ど土質定数の推定誤差など安定解析に関する様々な不確 定要素によって生じる安全率の誤差も考慮する必要があ る。現在一般的に採用されている計画安全率の值の妥当 性は経験的なものに負うところが大きく, 学術的な根拠 は明確でない。

採用した安定解析式の違いによる対策工効果の推定值 の違いも重要な問題である。この問題に関しては地すべ り研究者の中でも間違った認識が広がっているものもあ る。例えば簡便法による安全率が厳密解より常に小さく なるという考え方, その結果, 対策工の効果を過小に評 価するので安全側の設計となるとして簡便法を好評価す る考え方である。筆者の研究 ${ }^{17)}$ では解析対象中の $53 \%$ の 
地すべり地で簡便法の安全率が悠密解より $1 \%$ 以上小さ くなるものの，逆に $1 \%$ 以上大きくなる割合も $27 \%$ に達 する事が分かっている。仮に小さい安全率を算出すると しても，結果としてすべり面粘土のせん断強度定数を大 きな数值として評価することにつながり，対策工効果を 過大に評価する恐れがあると考えられるが，このことは 何らかの形で検証する必要がある。

様々な要因による安全率の誤差が対策工の効果推定に 大きく影響しているが，個別の現場事例について検証し た事例はあるものの汎用的な検証事例はほとんどない。 筆者らはこれまで数多くの地すべり地の安定解析や対策 工の効果推定を行い, 実在する地すべり地の縦断面デー 夕を用いて, 安定解析式による計算誤差の大きさや不確 定要素の影響などを調べてきた ${ }^{12)}$ 。対策工効果に与える 不確定要素の影響を汎用的に検証することにより，今後， 計画安全率の妥当性の検証に役立つと考える。

本論では，全国から集めた多くの現場事例を用いた一 連の研究の中で，いくつかの不確定要素についての対策 工効果への影響や代表的な安定解析式による対策工効果 の推定值の違いについて解析的に検証できたのでその結 果を報告する。

\section{2. 解析用現場事例データの概要}

解析に用いた事例デー夕は133現場分の 243 断面である。 ここでの現場数は同一の地すべり地であっても，異なっ た移動ブロックについてはそれぞれ別の現場として集計 した。同一ブロックについても比較的規模が大きい地す ベりで複数の縦断測線が設けられ，すべり面調査が行わ れている場合は, 主断面以外の縦断面デー夕も解析対象 とした。これらの事例は自然斜面での地すべり事例であ り，1〜2例の特例を除きそのほとんどが非円弧形の断 面形状を有している。

事例データの大まかな地質条件を図－1に示す。

事例データの地すべり規模は図 -2 に示すような弦長 $L て ゙$ 分類した。分類した地すべり規模の割合は図 -3 に 示すとおりである。

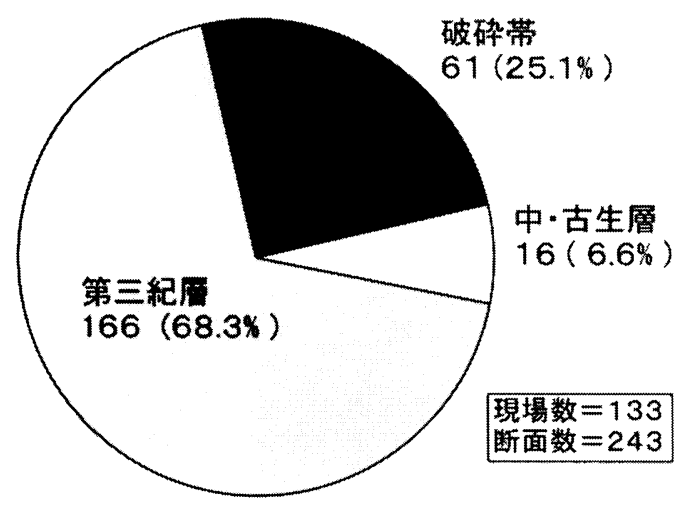

図-1 事例データの地質条件

Fig. 1 The Geologic classfication of case data

\section{3. 解析条件}

安定解析式には簡易な安定解析式でありながら比較的 計算誤差が小さいとされている簡易Janbu法を採用し， 安定解析式による違いを比較するために簡便法（Fellenius法）を用いた解析も行った。

安定解析における不確定要素にはさまざまなものがあ るが，今回検証した不確定要素の種類は表 1 に示す通り で，移動層の単位体積重量とすべり面深度，すべり面の 土質強度定数の 3 種類である。すべり面深度については 調査結果から得られた縦断面形を元に調查結果そのもの の場合と調查結果より $1 \mathrm{~m}$ 深い場合， $1 \mathrm{~m}$ 浅い場合の 3 つのケースを比較したが，データ加工処理を簡単にする ためにすべり面形を同一にしてすべり面からの土塊高さ のみを調整した（図ー4参照）。すべり面の土質強度定 数は粘着力 $c^{\prime}$ を 3 つ変化させて, 臨界水位での安全率

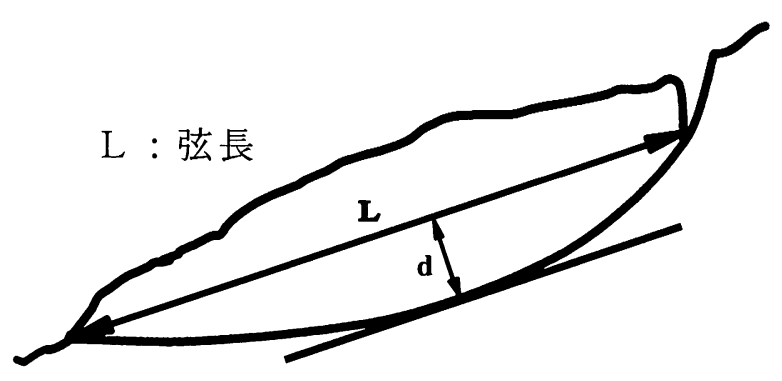

図一２断面形状の表現

Fig. 2 The expression of cross sectional form

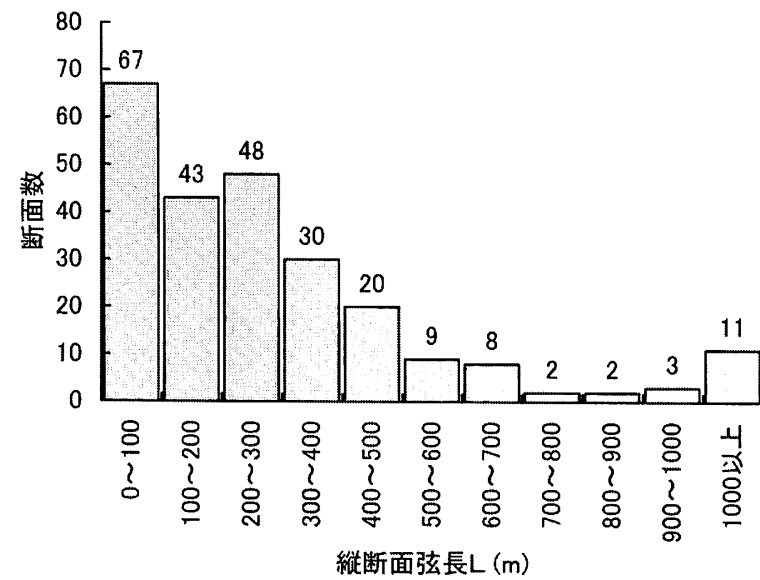

図ー3 事例デー夕の地すべり規模

Fig. 3 The landslide scale of case data

表ー1 検証した不確定要素と設定值

Table 1 The indefinite element and setting value which were verified

\begin{tabular}{|c|c|}
\hline 不確 定 要素 & 設 定 值 \\
\hline 移動層の単位体積重量 $\gamma\left[\mathrm{kN} / \mathrm{m}^{3}\right]$ & 18,20 \\
\hline すべり面深度 h & 調査値, 調查値+1.0, 調查値 -1.0 \\
\hline すべり面強度定数 " c' $\quad[\mathrm{kPa}]$ & $0,10,20$ \\
\hline 安定解析式 & 䉍易 Janbu 法, 簡便法 (Fellenius 法) \\
\hline
\end{tabular}




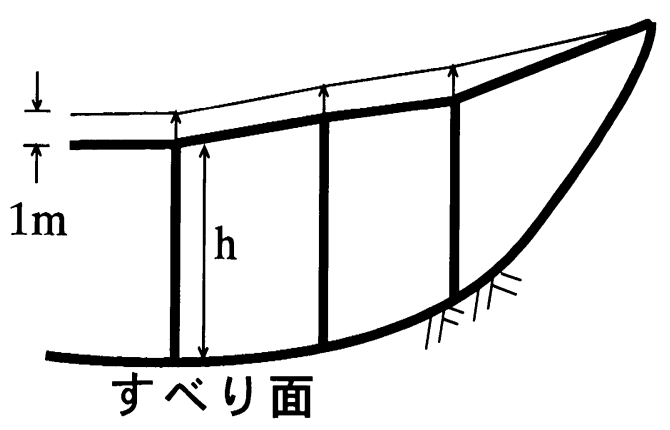

図ー4 すべり面深度条件の設定方法

Fig. 4 The setting method of slip surface depth conditions

$F$ を $F=1.0$ として $\phi^{\prime}$ 逆算解析で求めている。これらの 設定値は日常的に頻繁に起こり得る推定誤差を想定して いる。単位体積重量にしても $2 \mathrm{kN} / \mathrm{m}^{3}$ 程度の推定誤差は 容易に発生し得るし，すべり面深度の推定もパイプ歪み 計などの地中移動量観測ですべり面位置が確定している 場合でも $50 \mathrm{~cm}$ 程度の判定ミスが容易に生じ，それ以外 の条件では数mの推定誤差は容易に発生する。また，す ベり面の土質強度定数も残留強度であるとして $c^{\prime}=0$ $\mathrm{kPa}$ とする場合と $c^{\prime}=h$ (最大すべり面深度 $\mathrm{m}$ ) $\mathrm{kPa}$ とした 場合などで容易に発生する推定誤差の範囲にある。

上記 3 種類の不確定要素の影響が安全率に与える影響 についてはすでに学会で発表しているが2), 不確定要素 の影響によって地すべりの安全率が最大 $8 \%$ 26\%程度 の範囲で変化することなど分かっている。本研究では対 策工効果への影響に着目し，地下水排除工，排土工，抑 止工の効果推定值に与える影響を調べた。

地下水排除工による地下水位低下量は地すべり地内に 8 基の集水井を施工した場合の水位低下量の分布を定常 解析の群井理論で算出した。 8 基の集水井による水位低 下量は地すべり地や断面によって異なるため，異なる断 面間で地下水排除工効果の対比はできないが, 同一断面 での比較は可能である。

排土工は地すべり頭部を一般的な任意の形状で排土し た断面形で検討した。

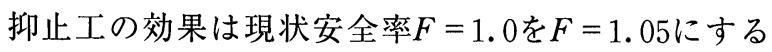
ために必要な単位幅当りの必要抑止力 $P_{u}$ を算出して比 較したが, 安定解析式の分子項に $P_{u}$ が作用するとした 次式の值を採用した。

$$
F=f_{0} \frac{\Sigma S+P_{u}}{\Sigma T}
$$

ここに， $f_{0}$ : 修正係数, $\Sigma S, \Sigma T$ : 安定解析式にお ける分子項と分母項の総和

スライス内の力の釣り合いから誘導すると必要抑止力 などの力は必ず安定解析式の分母項に作用するが，ここ ではそのことを無視して慣用的に用いられている方法に 準拠した。

不確定要素の違いにより必要抑止力が変化することは, 所定の安全率を確保するために必要な抑止力が変化する
表一 2 計算条件

Table 2 Calculation conditions

\begin{tabular}{|c|c|c|c|c|}
\hline 条件番号 & 安定解析式 & 単位体積重量 & 粘着力 $c^{\prime}$ & すべり面深度 \\
\hline 001 & 簡易 Janbu & $18 \mathrm{kN} / \mathrm{m}^{3}$ & $0 \mathrm{kPa}$ & 調査値 \\
\hline 002 & 簡易 Janbu & $20 \mathrm{kN} / \mathrm{m}^{3}$ & $0 \mathrm{kPa}$ & 調査值 \\
\hline 003 & 簡易 Janbu & $18 \mathrm{kN} / \mathrm{m}^{3}$ & $10 \mathrm{kPa}$ & 調査值 \\
\hline 004 & 簡易 Janbu & $18 \mathrm{kN} / \mathrm{m}^{3}$ & $20 \mathrm{kPa}$ & 調査値 \\
\hline 005 & 簡易 Janbu & $18 \mathrm{kN} / \mathrm{m}^{3}$ & $0 \mathrm{kPa}$ & 調査値 $-1 \mathrm{~m}$ \\
\hline 006 & 簡易 Janbu & $18 \mathrm{kN} / \mathrm{m}^{3}$ & $0 \mathrm{kPa}$ & 調査値 $+1 \mathrm{~m}$ \\
\hline 301 & 簡便法 & $18 \mathrm{kN} / \mathrm{m}^{3}$ & $0 \mathrm{kPa}$ & 調査値 \\
\hline 302 & 簡便法 & $20 \mathrm{kN} / \mathrm{m}^{3}$ & $0 \mathrm{kPa}$ & 調査值 \\
\hline 303 & 簡便法 & $18 \mathrm{kN} / \mathrm{m}^{3}$ & $10 \mathrm{kPa}$ & 調查値 \\
\hline 304 & 簡便法 & $18 \mathrm{kN} / \mathrm{m}^{3}$ & $20 \mathrm{kPa}$ & 調查値 \\
\hline 305 & 簡便法 & $18 \mathrm{kN} / \mathrm{m}^{3}$ & $0 \mathrm{kPa}$ & 調査値 $-1 \mathrm{~m}$ \\
\hline 306 & 簡便法 & $18 \mathrm{kN} / \mathrm{m}^{3}$ & $0 \mathrm{kPa}$ & 調查値 $+1 \mathrm{~m}$ \\
\hline
\end{tabular}

ということであり，逆にいえば同じ抑止力を期待して採 用した抑止工でも不確定要素によって達成される安全率 が変わるといことである。つまり，所定の達成安全率に 対する必要抑止力 $P_{u}$ を比較することで, 抑止工効果の 大小が比較できることになる。これはすべての抑止工に 共通である。

対象とする不確定要素を組み合わせて計算条件を設定 した。表 2 に計算条件を示す。何れの条件も排土前の現 状断面で臨界水位時の安全率 $F$ が $F=1.0$ となるように 内部摩擦角 $\phi^{\prime}$ 決定している。その臨界水位の状態から 各対策工を施工した場合に達成する安全率または必要抑 止力を算出して比較した。

\section{4. 解析結果}

\section{1 不確定要素の推定誤差による対策工効果推定值 の違い}

（1）単位体積重量の影響

図 - 5 は単位体積重量 $\gamma$ 違いが抑制工の効果推定に 与える影響を調べたものである。横軸は対策工効果の変 動率であるが, これは $\gamma=20 \mathrm{kN} / \mathrm{m}^{3}$ の場合に達成する安 全率を $\gamma=18 \mathrm{kN} / \mathrm{m}^{3}$ の場合の達成安全率で割り, その比 が1.0より何\%上下するかをみたものである。以下，変 動率と表現した場合は比較対象值の比を百分率で表示し た比率が100\%の場合を0\%として比率の差を表したも のとする。図－ 5 で変動率が負の值になるということは $\gamma=20 \mathrm{kN} / \mathrm{m}^{3}$ の場合の達成安全率が $\gamma=18 \mathrm{kN} / \mathrm{m}^{3}$ の時より 小さいことを示す。縦軸は変動率の範囲毎の該当する断 面数である。

図 - 5(a)の地下水排除工の工事効果は $0 \sim-1 \%$ 範 囲に入る断面が最も多く, 0 〜 - $6 \%$ の範囲に全体の 98\%の断面が含まれる。つまり，地下水排除工の効果推 定值は〉が小さいほど大きくなり，実際より小さなとで 地下水排除工の効果を推定すると効果を過大に評価する 
ことになる。

図-5(b)は同様の方法で頭部排土工の効果推定值の差 異を調べたものであるが，変動率が $\pm 1 \%$ 以内に収まる

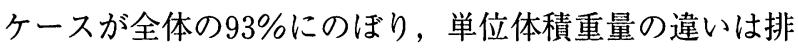
土工効果にあまり影響しないことがわかる。

図一 5 (c)は地下水排除工と頭部排土工を併用した場合 の効果を調べたものであるが，地下水排除工の影響が大 きく，図-5(a)とほほ同じ分布形になっている。工事効 果の変動の大きさは $11 \%$ のの推定誤差に対して最大 8 \%程度, 全体の $99 \%$ $6 \%$ 以内の変動率内に収まってい る。rの推定誤差に比べると対策工効果の変動は小さい。

図-6は同じく単位体積重量の推定誤差の影響が抑止 工の効果推定に与える影響を調べたものである。横軸の 必要抑止力の変動率は $\gamma=20 \mathrm{kN} / \mathrm{m}^{3}$ の場合の必要抑止力 を $\gamma=18 \mathrm{kN} / \mathrm{m}^{3}$ の場合の值で割った比が 1.0 より何\%上下 するかをみたものである。抑止工の必要抑止力は安定解

(a) 地下水排除工

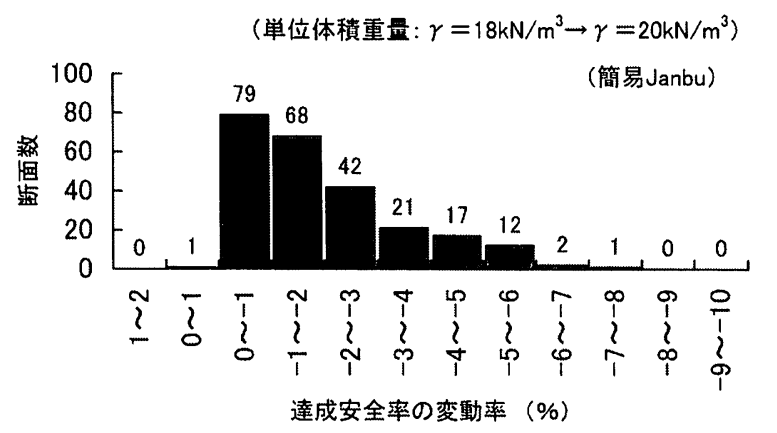

(b) 頭部排土工

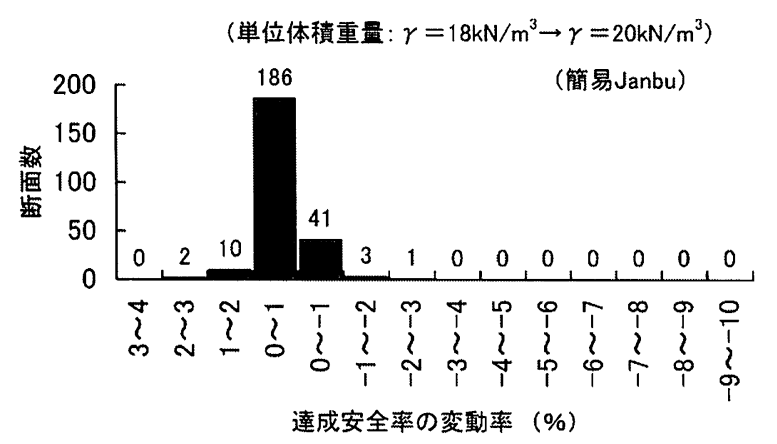

(c) 地下水排除工 + 頭部排土工

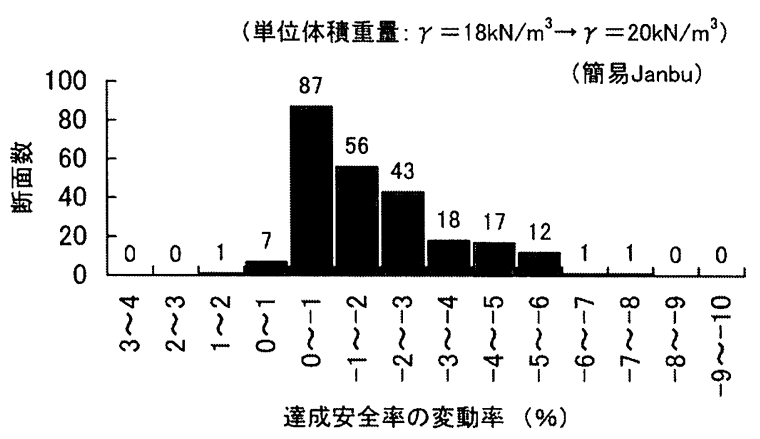

図ー 5 単位体積重量の違いによる抑制工の達成安全率の変動

Fig. 5 The change of the achievement safety factor of control works by the difference in unit volume
析分母項の $\Sigma T$ に左右されるため $11.1 \%$ 増加する変動率が期待される。図－6では変動率 11 12\%が全体の $80 \%$ となっている。簡便法では式の性 質上, $\gamma$ の比と必要抑止力の比は完全に一致する。当然 の事ながらてが大きくなると所定の安全率を確保するた めの必要抑止力は増加する。逆にいえば々が大きくなる と同じ規模の抑止工で得られる達成安全率が小さくなる というこである。

つまり，抑止工の場合も実際より小さなとで工事効果を 推定すると効果を過大に評価することになり，その工事 効果推定の変動の大きさはrの推定誤差とほぼ同じになる。

(2) すべり面の土質強度定数の影響

図 - 7 は前項と同様の手法ですべり面の土質強度定数 の影響を調べたものである。 $c^{\prime}=0 \mathrm{kPa}$ の場合と $c^{\prime}=10$ $\mathrm{kPa}$ の場合を比較している。

図ー7(a)をみると最頻值が $0 \sim-1 \%$ $0 \sim-11 \% に$ 全体の $94 \%$ 集中している。地下水排除工の効果は $c^{\prime}$ を 大きく推定すると工事効果を小さく推定することになる。 $5 \%$ よ大きい変動率の頻度は約 $30 \%$ あ゙あ，この程度 の効果推定值の差異は頻繁に発生することがわかる。

排土工に関する効果推定値の変動率は 0 〜 - $1 \%$ が最 頻值であるが，+4\%〜 - 3\%の間に $92 \%$ \%含まれる。 つまり, 土質強度定数の推定誤差による排土工効果の推 定は過大になる場合と過小になる場合があり, 今回の設 定值程度の $c^{\prime}$ の違いではほとんどの場合 $4 \%$ 程度以内の 推定値の違いになる。

地下水排除工と排土工を併用した場合の変動率の頻度 分布図（図ー7(c)）はそれぞれの分布パターンをそのま ま加算したような分布形となっている。

$c^{\prime}=0 \mathrm{kPa}$ と $c^{\prime}=20 \mathrm{kPa}$ との比較では何れの抑制工の場合 も変動率の頻度ピーク位置は図ー 7 とほぼ同じであるが, ピーク位置での頻度は小さくなり分布範囲が若干広がる。

図ー8は同じく抑止工の効果推定におよばす影響を調 べたものである。推定值の変動率は $0 \sim+1 \%$ 最頻值 で全体の $38 \%$ が分布し， $0 \sim+9 \%$ 間に全体の $96 \%$ が 分布している。つまり，土質強度定数による抑止工の効 果推定の差異が比較的小さい地すべりは全体の $38 \%$ と多 いものの, 変動率のほとんどが正の值であることから,

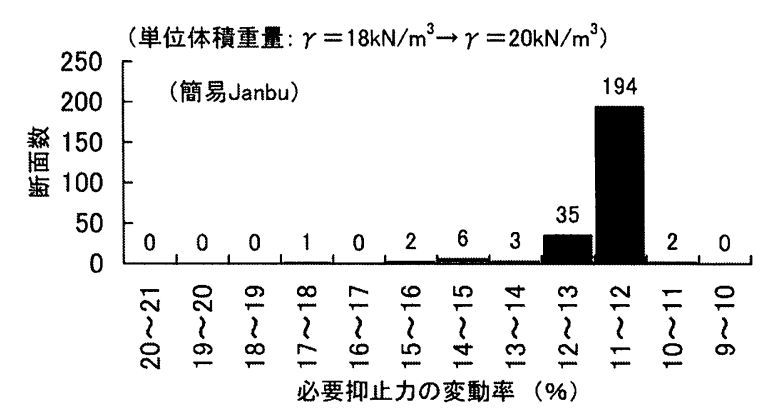

図ー6 単位体積重量の違いによる抑止工の必要抑止力の変動

Fig. 6 The change of the required deterrent of prevention works by the difference in unit volume 
(a) 地下水排除工

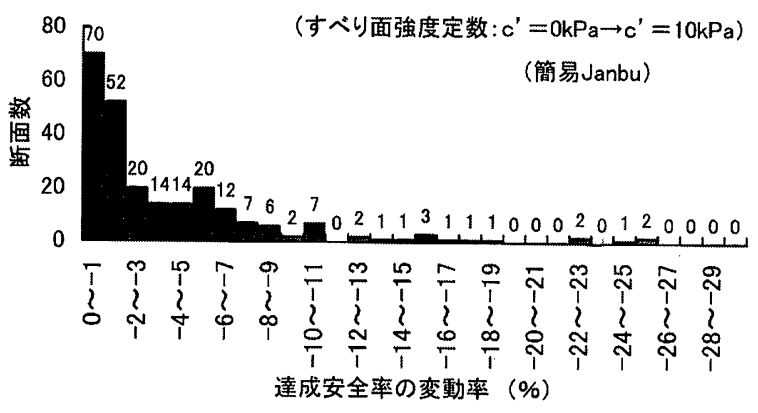

(b) 頭部排土工

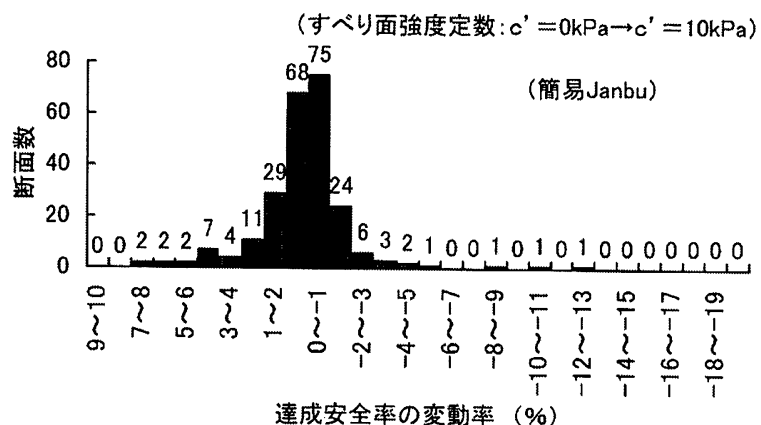

(c) 地下水排除工 + 頭部排土工

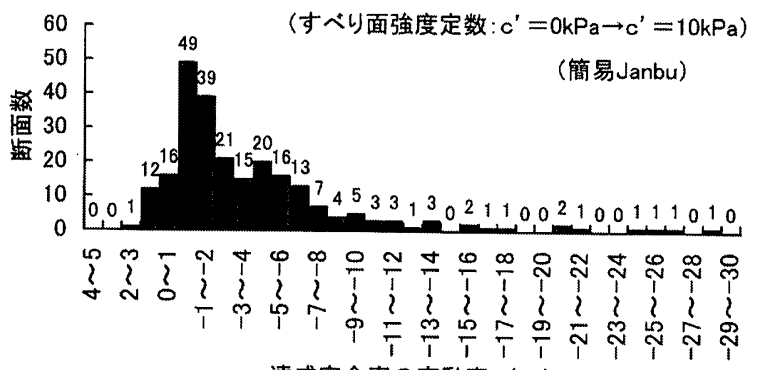

達成安全率の変動率（\%)

図ー 7 すべり面強度定数の違いによる抑制工の 達成安全率の変動

Fig. 7 The change of the achievement safety factor of control works by the difference in shear strength of slip surface clay

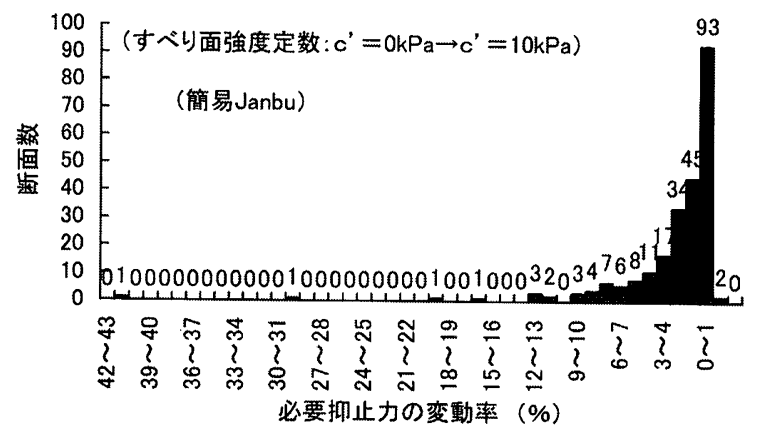

図ー8 すべり面強度定数の違いによる抑止工の 必要抑止力の変動

Fig. 8 The change of the required deterrent of prevention works by the difference in shear strength of slip surface clay $c^{\prime}$ を大きくすると所定の安全率を確保するための必要抑 止力が大きくなる傾向にあるといえる。

(3) すべり面深度の影響

図 - 9 はすべり面深度が地下水排除工の効果推定に与 える影響を調べたものである。最頻值は 0 〜 - $1 \%$ で，

$0 \sim-10 \% に$ 全体の $98 \%$ が分布している。すべり面深度 を実際より深く推定すると地下水排除工の効果を小さく 評価することになり，1 $\mathrm{m}$ の違いで最大 $10 \%$ 程度小さく 評価することがわかる。

変動率の頻度分布の形状は単位体積重量を増加させた場 合と類似している。抑止工に対する影響も単位体積重量 を変化させた場合と同様であることからここでは割愛する。

$h \rightarrow h-1 \mathrm{~m}$ の場合の頻度分布図は図 -9 の変動率の 正負を逆転させた分布となる。

\section{2 地すべり規模との関係で調べた対策工効果推定 値の違い}

対策工毎の効果推定の違いを地すべりの規模との関係 で調べた結果を示す。

図－10は地下水排除工の効果推定值の違いを地すべり 規模との関係で表示し，不確定要素の種類毎に比較した ものである。ここでは, 効果推定值の違いをわかりやす いように達成する安全率の差で表現した。横軸にはすべ り規模を代表する值として地すべりの断面形における弦 長 $L$ を採用した。縦軸は地下水排除工による達成安全率 の差である。不確定要素の推定誤差の影響が無ければ, 達成安全率の差は 0.0 近傍に分布することになる。図中 の点線や 1 点鎖線は視覚的な境界を示したものであるが, 分布形の特徴がこの 2 つの線の付近を境に変化している ように思われる。図－5(a)と図－10(a)を比較すると，同 じ単位体積重量と地下水排除工に関する解析結果であり ながら，前者ではデー夕分布が+ $1 \%$ - 8\%であるの に対し，後者は $0.01 〜-0.12$ まで分布しており，数字が 合わない。これは地下水排除工によって達成する安全率 が $F>1.0 て ゙ ，$ 事例毎にその值が異なることに起因する。

3 つの不確定要素ともに分布形は類似しており, 弦長 Lが小さいほど安全率差のバラッキが大きくなっている。

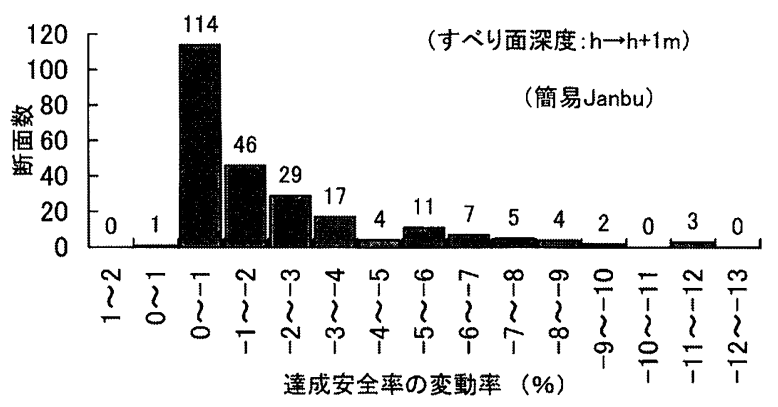

图ー9 すべり面深度の違いによる地下水排除工の 達成安全率の変動

Fig. 9 The change of the achievement safety factor of groundwater drainage works by the difference in slip surface depth 
弦長が大きい場合はどの不確定要素の場合も安全率差は 約0.02以内であるが, 弦長が小さい地すべりでは単位体 積重量の場合で最大 0.12 程度, 土質強度定数の場合で最 大 0.4 程度，すべり面樑度の場合で最大 0.17 程度となっ ている。不確定要素の推定誤差の大きさがこれより大き くなれば当然この達成安全率の差は增大する。視覚的に 判断すると分布形状態が弦長 $L=400 \sim 500 \mathrm{~m}$ 付近で変化 しているようにみることもできる（図中の点線）。また， 安全率差が 0.1 越える地すべりは弦長 $L$ が $200 \mathrm{~m}$ 以内の 地すべりに多い。

図-11は前項と同様に地すべり規模と頭部排土工効果 推定値の差の関係を調べたものである。地下水排除工の 場合と比較すると安全率の差が正負両方に分布するとい う違いはあるものの弦長 $L$ に関係する分布形の違いは顕 著ではない。また達成安全率の差のバラッキの大きさも 地下水排除工に比べて小さい。

（a）単位体積重量による影響

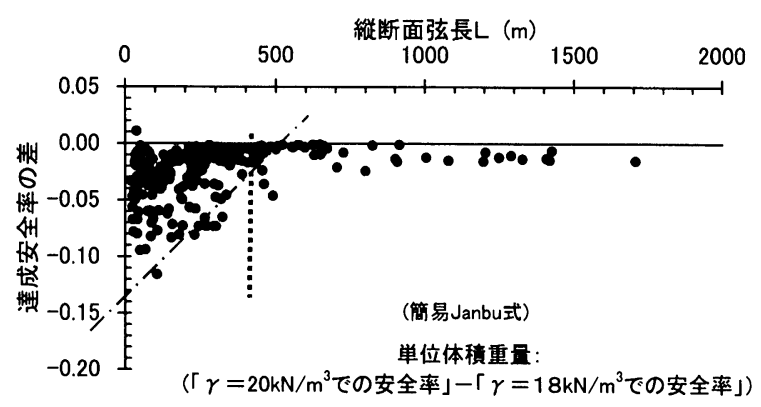

（b）土質強度定数による影響

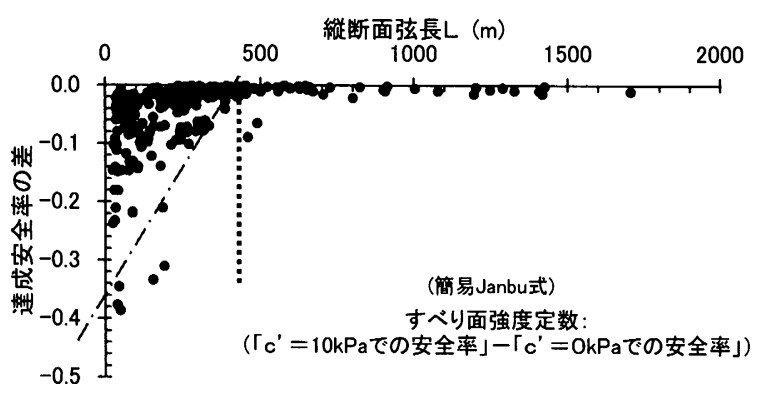

(c) すべり面深度による影響

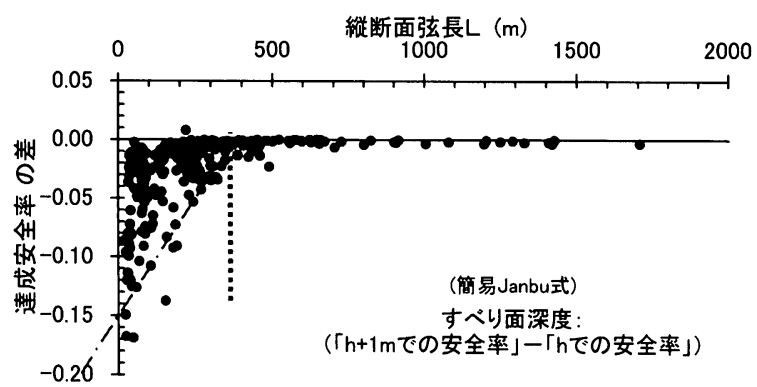

図一10地すべり規模との関係から見た地下水排除工の 達成安全率の変動

Fig. 10 The change of the achievement safety factor of groundwater drainage works judged from the relation with the landslide scale
地下水排除工と頭部排土工を併用した場合の達成安全 率の差の分布図を図-12に示すが，両対策工単独の場合

（a）単位体積重量による影響

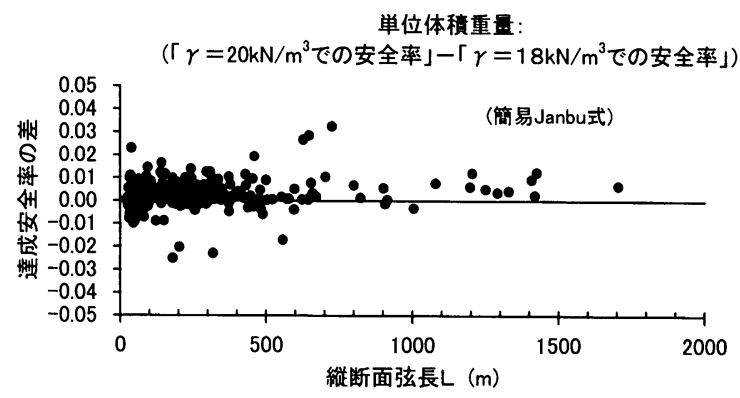

（b）土質強度定数による影響

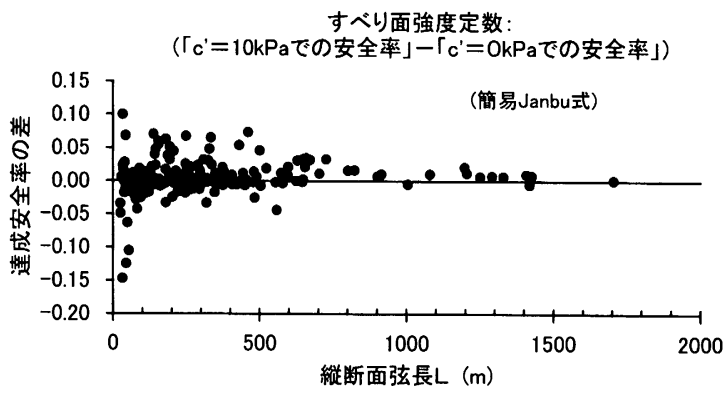

図ー11地すべり規模との関係から見た排土工の 達成安全率の変動

Fig. 11 The change of the achievement safety factor of soil removal works judged from the relation with the landslide scale

(a) 単位体積重量による影響

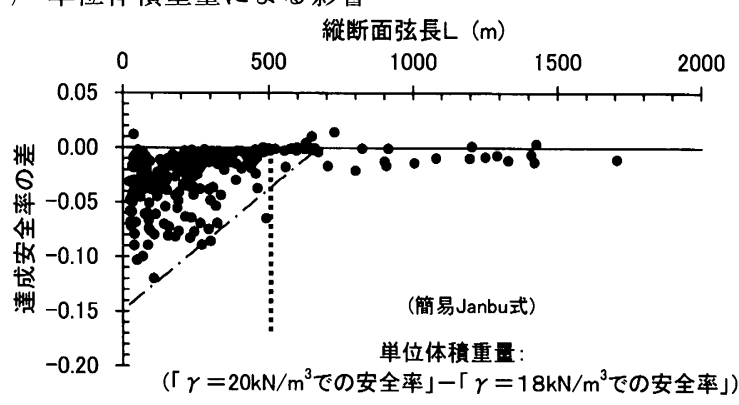

（b）土質強度定数による影響

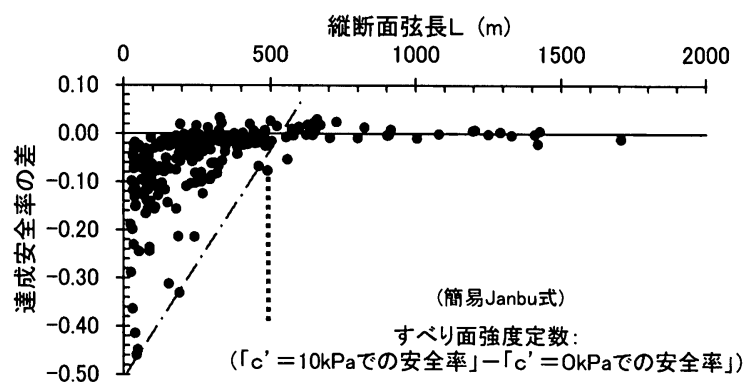

図ー12 地すべり規模との関係から見た抑制工併用の 達成安全率の変動

Fig. 12 The change of the achievement safety factor of combined control works judged from the relation with the landslide scale 
の分布形をそのまま重ね合わせたような分布形となって いる。特徵的なことは図ー12(b)に示すように地下水排除 工単独では最大の達成安全率差がー0.38程度であったの に対し，対策工を併用することで最大の差が約ー0.46に 増大していることである。1つの不確定要素による対策 工効果の推定誤差が対策工を併用することにより増大す る場合があることが確認された。

\section{3 不確定要素推定誤差の重ね合わせ効果}

図ー13は 3 つの不確定要素を組合せた場合の地下水排 除工の効果推定における達成安全率の差の分布を調べた ものである。

図-13(a)は単位体積重量 $\gamma$ 土質強度定数の推定誤差 を組合せた場合の分布図であるが，当然両者単独の場合 の達成安全率差を加算した分布形になる。つまり，この 図の縦軸值は図ー10(a)の縦軸值の符号を逆にした值と図 -10(b)の值を加算したものと同值になるので, 達成安全 率の差が正の場合は単位体積重量の推定誤差の影響が強

（a）単位体積重量と土質強度定数の影響

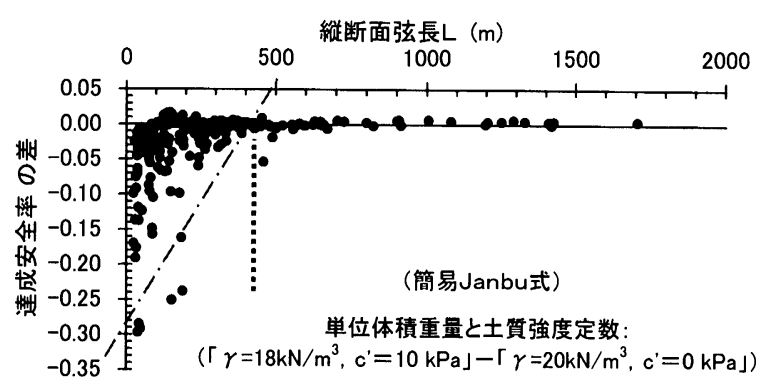

(b) すべり面深度と土質強度定数の影響

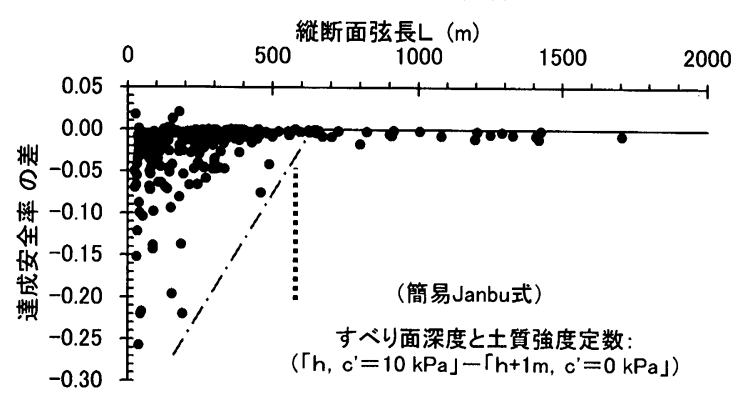

(c) 単位体積重量とすべり面深度の影響

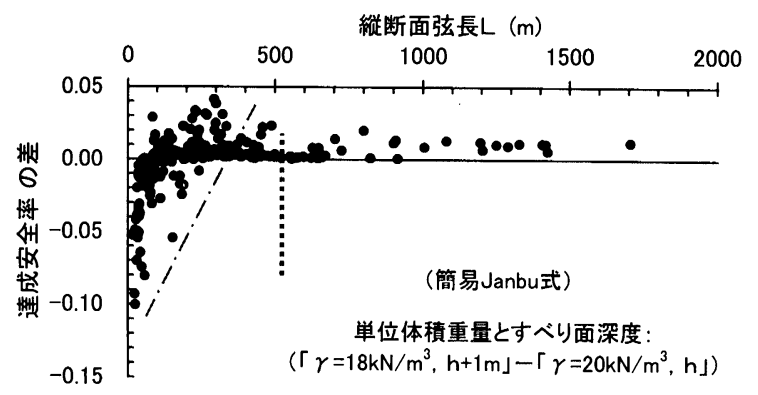

図ー13 不確定要素の推定誤差の重ね合わせによる 地下水排除工の達成安全率の変動

Fig. 13 The change of the achievement safety factor of groundwater drainage works by superposition of the presumed error of indefinite elements
く，負の場合は土質強度定数の推定誤差の影響が大きい と概観することができる。図ー13(a)で特徵的なことは弦 長が短い地すべりでは土質強度定数の影響が優勢であり 弦長 $L$ が長い地すべりでは逆に単位体積重量の影響が優 勢となっている。また，負の值は一0.30付近まで分布し 土質強度定数の影響を強く受けた地すべりが複数存在す るのに対し, 単位体積重量の影響を受けた正の值は+ 0.02 程度以下であり，対策工効果推定に大きな影響がで ていない。

図-13(b)はすべり面深度と土質強度定数の組合せであ るが, 達成安全率の差が正の值となるものは前者の推定 誤差による影響, 負となるものは後者の影響であると見る ことができる。弦長の長短にほぼ関係なく土質強度定数 の影響が優勢となっている。安全率の差が+0.01以上とな る事例はこの中で 3 件のみであり, 残りのほとんどの現 場事例ではすべり面深度の影響は無視できる程度である。

図ー13(a)にも共通することであるが，土質強度定数の 影響を受けた負側の安全率差ー0.05以下の事例は多く存 在するのに対して, 正側の +0.03 以上となる事例は皆無 である。図ー10を見ると単位体積重量やすべり面深度の 単独の影響で最大 0.05 以上の安全率差が生じる事例は数 多く存在しているにも関わらず，図ー13(a)(b)ではそれら の影響を強く受けた事例はほとんど無い。つまり, 図一 13(a)(b)で安全率差が0.0付近より下にある程度離れてい る事例は土質強度定数の推定誤差の影響は強く受けるが もう一方の影響はあまり受けない地すべりで，0.0付近 に分布する事例にはどちらの不確定要素の影響もあまり 受けないものと, 両方の不確定要素の影響を同程度に強 く受けるものがあると判断できる。

図-13(c)は単位体積重量とすべり面深度の組合せで, 正の值が前者の影響，負の值が後者の影響である。縦軸 の正負の分布状況を詳しく見ると弦長 $L$ が $100 \mathrm{~m}$ 程度よ り短い地すべりではすべり面深度の影響が優勢となり, 弦長がそれより長い地すべりでは単位体積重量の影響が 優勢になっていることがわかる。

図－14は頭部排土工および頭部排土工と地下水排除工 の併用における推定䛊差の重ね合わせ効果を調べたもの である。頭部排土工がからむため不確定要素の組合せは 単位体積重量と土質強度定数のみである。

図 - 14(a)の頭部排土工のみの場合の安全率差の分布は 図-11(b)の土質強度定数の違いによる分布とほぼおなじ 分布状態であり，ここでも土質強度定数の影響が大きい ことがわかる。もともと排土工の効果推定に関する単位 体積重量の影響は小さいことを図は 5 (b)で示したが，そ のことが現れた結果となった。同様の理由から図ー14(b) の頭部排土工と地下水排除工の併用の場合も図-13(a)の 地下水排除工単独の場合の分布状態とほぼ同じである。

上記の計算事例は安全率差を小さくする設定值の組合 せで比較したが，逆にどちらも安全率差を大きくするよ うな組合せであれば安全率差は加算されることになる。 
(a) 頭部排土工

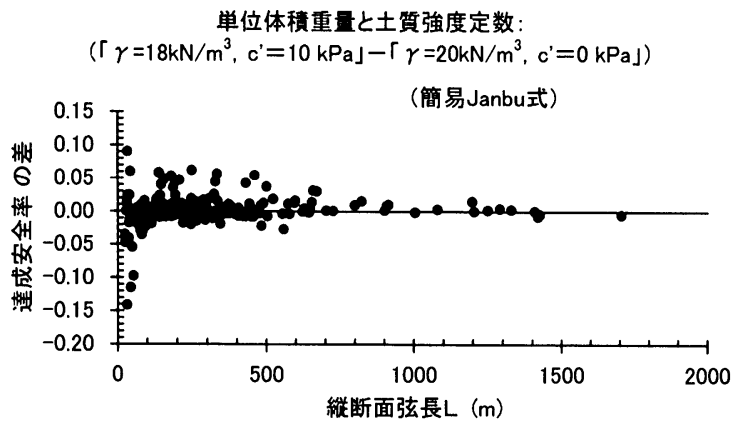

（b）地下水排除工＋頭部排土工

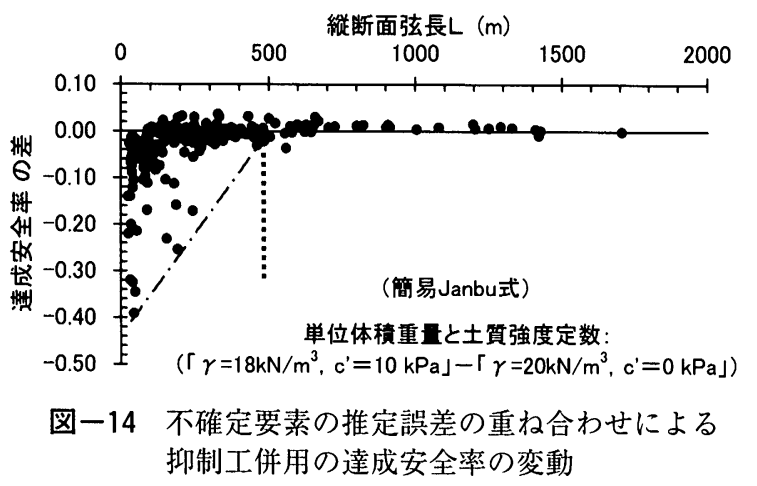

Fig. 14 The change of the achievement safety factor of combined control works by superposition of the presumed error of indefinite elements

\section{4 安定解析式の違いが対策工効果推定値に与える 影響}

図-15は安定解析式の違いが抑制工の効果推定に与え る影響を調べたものである。横軸が対策工効果の変動率 であるが，簡便法の場合に達成する安全率を簡易Janbu 法の達成安全率で割り，その比が1.0より何\%上下する かをみたものである。変動率が正の值になるということ は簡便法による達成安全率が大きいということになる。

図－15(a)の地下水排除工に関しては全体の $98 \%$ の地す べりで簡便法による対策工効果が大きく算出されるが, ほぼ差がないと認められる変動率の絶対值 1\%未満の地 すべりが144件 (59.2\%) と大半を占める。変動率は $4 \%$ 程度までの頻度が高い。

図－15(b)の頭部排土工に関しては $0 \sim 1 \% の$ 変動率の 地すべりが多く，分布形はほほ左右対称である。つまり， 簡易Janbu法の効果が大きく算出される地すべりとその 逆となる地すべりの割合はほほ同じであり，その変動率 の範囲は+5\%〜 - 8\%程度であることがわかる。

図-15(c)は地下水排除工と頭部排土工を併用した場合 のものであるが，分布形は頭部排土工の場合の分布とほ ぼ同じであるが，変動率のピーク位置での頻度が減少し， 変動率が 1 〜 \%の範囲で頻度が大きく増加している。 これは両者の効果推定值の変動がそのまま合算されたと 考えると見ることができる。

図-16は安定解析式の違いが抑止工の効果推定に与え る影響を調べたものであるが，手法は不確定要素による (a) 地下水排除工

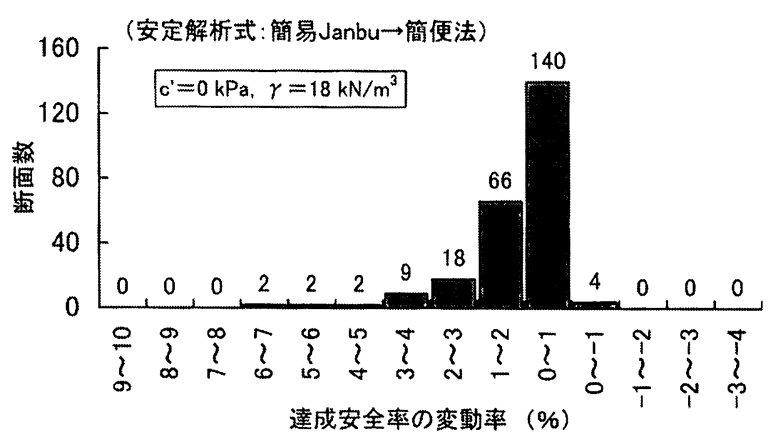

(b) 頭部排土工

（安定解析式:簡易Janbu $\rightarrow$ 簡便法）

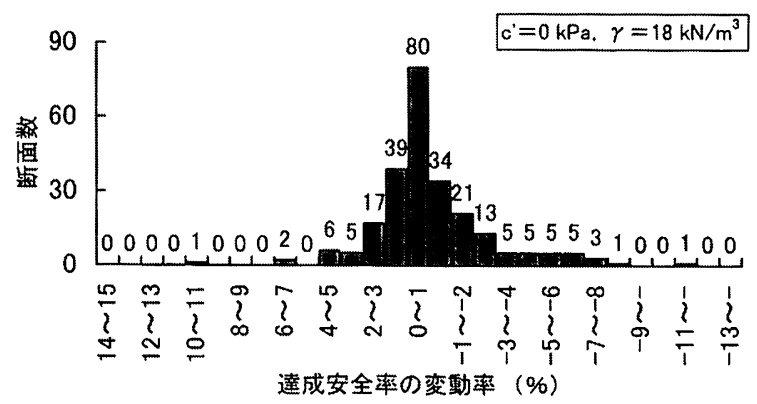

（c）地下水排除工 + 頭部排土工

（安定解析式:簡易Janbu $\rightarrow$ 簡便法）

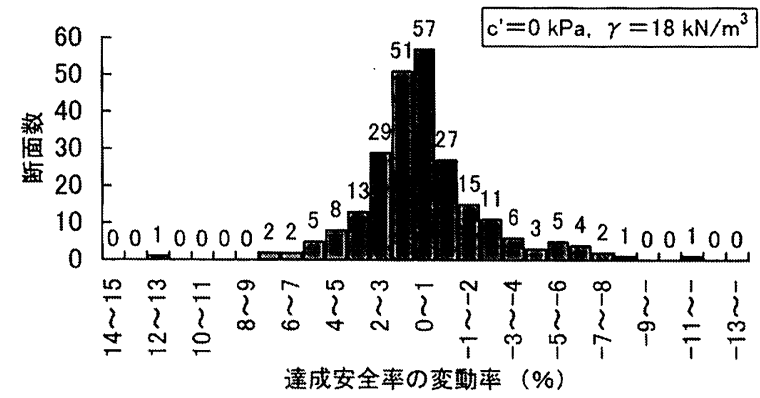

図一15 安定解析式の違いによる抑制工の達成安全率の変動 Fig. 15 The change of the achievement safety factor of control works by the difference in stability analysis method

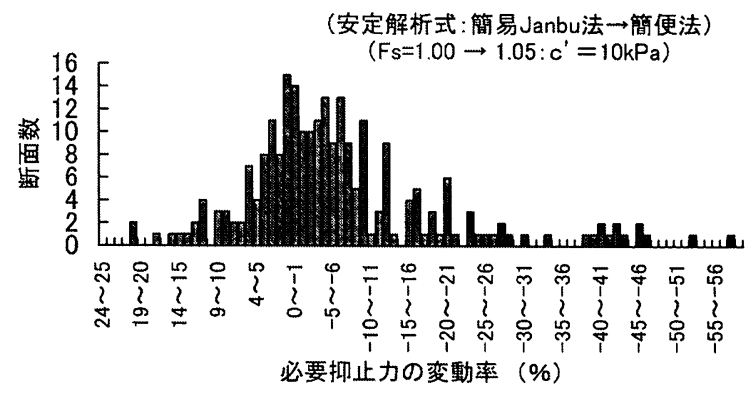

図ー16 安定解析式の違いによる抑止工の必要抑止力の変動

Fig. 16 The change of the required deterrent of prevention works by the difference in stability analysis method

影響を調べた手法と同じである。横軸の必要抑止力の変 動率が正の場合は簡便法による必要抑止力が大きくなる ということであり，逆に言えば同一の規模の抑止工で達 
成される安全率は簡便法の方が小さい地すべり地という ことである。

この図での最頻值は 0 〜 $1 \%$ で，正負両方の変動率が 分布するが, 負の変動率の方が分布範囲も広く分布数も 多い。つまり，簡易Janbu法による必要抑止力が大きく なる場合が多いことを意味している。変動率の分布範囲 は+20\%〜ー58\%であるが，抑止工による負担安全率が $5 \%$ あることから安全率の変動率に単純換算すると $1 \%$ ー 3\%となる。

簡易Janbu法と簡便法のどちらが対策工の効果を大き く評価するかを対策工毎に比較した表が表－3である。 $1 \%$ 未満の違いはほぼ同值であると判断し, 簡易Janbu 法による工事効果が $1 \%$ 以上大きくなる割合を示したの が括弧内の数字である。これによると地下水排除工の効 果は常に簡便法の方が大きく評価され，その他の対策工 では 6 割から 7 割の地すべり地で簡便法の方が効果をよ り大きく算出する。 6 割から 7 割という比率は抑制工も 抑止工もほぼ同じである。

図ー17と図－18は安定解析式の違いによる抑制工と抑 止工に関する対策工効果の違いを地すべり規模との関係 でみたものである。地下水排除工だけは弦長 $L か ゙$ 短いも のほど誤差のバラツキが大きいことがわかるが，その他 の対策工については明瞭な傾向は現れない。

前節までの不確定要素に伴う対策工効果推定值の差異 については簡便法でも評価したが，簡便法での変動率の 分布も簡易Janbu法によるものとほとんど同じであった。

\section{5. 考察}

不確定要素による対策工効果の推定值の差異は不確定 要素の種類によってその大きさや発生頻度分布が異なる が，対策工の種類による分布状況の違いがより大きいこ とがわかった。また，不確定要素の組合せによる対策工 効果推定值の差異は加算されるものもあるが，相殺され るものやどちらか一方の影響のみが優勢になるものもあ る。現時点ではこれらの法則性を見いだすまでには至っ ていないが，次のような事実が確認された。

(1)地すべり縦断面の弦長 $L$ が短い地すべりほど不確定

\section{表ー3 簡易Janbu法による工事効果が簡便法より} 大きく算出される地すべりの割合

Table 3 The rate of the landslide by which the construction effect by the simple Janbu method is computed more greatly than the Fellenius method

\begin{tabular}{|c|c|c|}
\hline \multicolumn{2}{|r|}{ 対策工の種類 } & 地すべり地の割合 \\
\hline \multicolumn{2}{|c|}{ 地下水排除工 $\left(c^{\prime}=0 \mathrm{kPa}, \quad \gamma=18 \mathrm{kN} / \mathrm{m}^{3}\right)$} & $1.6 \% \quad(0 \%)$ \\
\hline \multicolumn{2}{|c|}{ 頭部排土工 } & $38.3 \% \quad(24.3 \%)$ \\
\hline \multicolumn{2}{|c|}{ 地下水排除工＋頭部排土工 } & $30.9 \% \quad(19.8 \%)$ \\
\hline \multirow{2}{*}{ 抑止工 } & $\left(\mathrm{c}^{\prime}=0 \mathrm{kPa}, \quad \gamma=18 \mathrm{kN} / \mathrm{m}^{3}\right)$ & $43.2 \% \quad(36.6 \%)$ \\
\hline & $\left(\mathrm{c}^{\prime}=10 \mathrm{kPa}, \quad \gamma=18 \mathrm{kN} / \mathrm{m}^{3}\right)$ & $31.4 \% \quad(25.1 \%)$ \\
\hline
\end{tabular}

（ ）内の数字は $1 \%$ 以上大きい場合の割合
要素の推定誤差の影響を強く受ける地すべりが多い。 特に弦長 $L$ が $200 \mathrm{~m}$ 以下の地すべりは対策工効果の推

(a) 地下水排除工

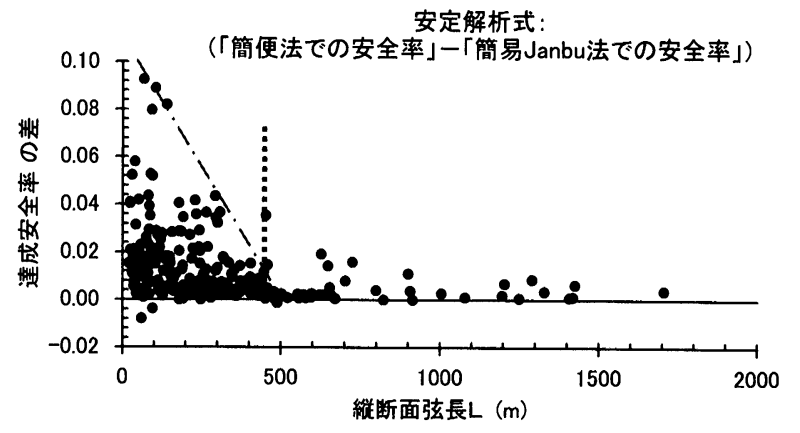

(b) 頭部排土工

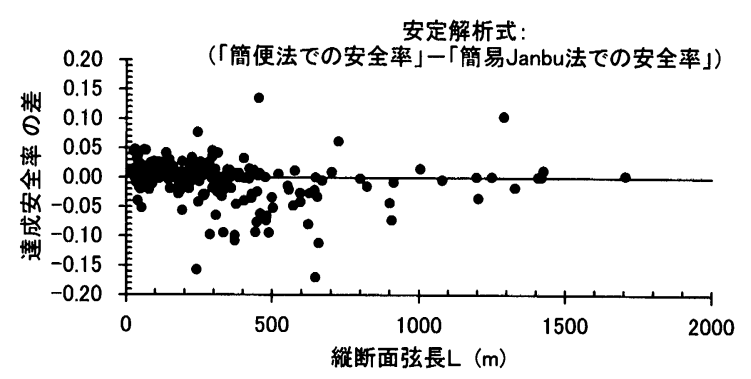

(c) 地下水排除工 + 頭部排土工

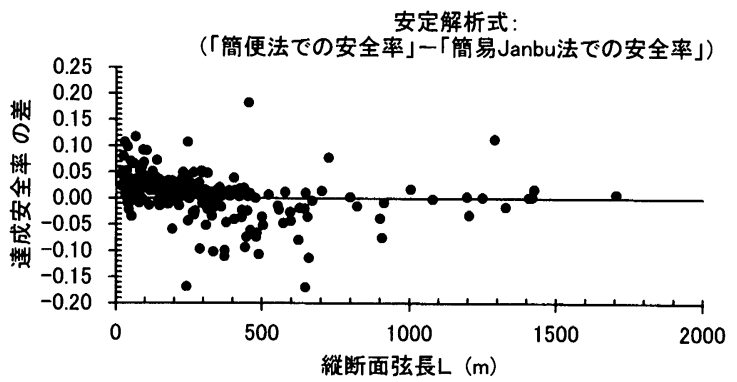

図-17 安定解析式の違いによる抑制工の達成安全率の 変動と地すべり規模の関係

Fig. 17 The relation between the achievement safety factor of control works by the difference in stability analysis method and landslide scale

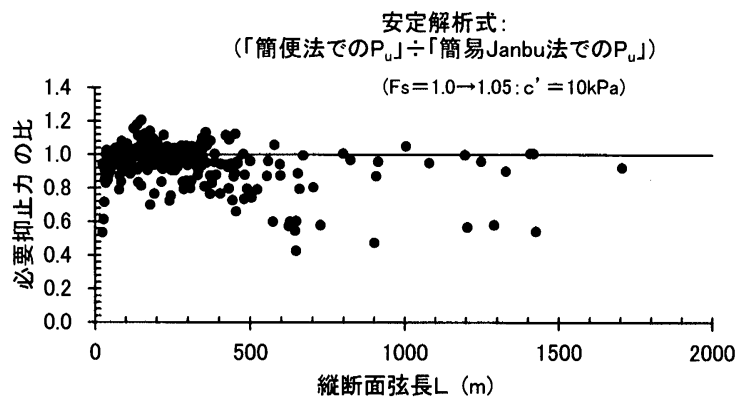

図ー18 安定解析式の違いによる抑止工の必要抑止力の 変動と地すべり規模の関係

Fig. 18 The relation between the required deterrent of prevention works by the difference in stability analysis method and landslide scale 
定值に安全率差で0.2以上の大きな差異を生じる場合 がある。多くのケースでは弦長 $L か ゙ 500 \mathrm{~m}$ 越える と不確定要素による効果推定値の差異は小さくなる。 (2) 1 つの不確定要素による対策工効果推定值の差異が 対策工を併用することにより増大し, 安全率の差に して0.46程度の大きな推定差異が生じることもある （土質強度定数による影響，図一12(b))。

(3)土質強度定数の推定誤差の影響を強く受ける弦長の短 い地すべりの中には単位体積重量やすべり面深度の 推定誤差の影響をあまり受けない事例が多く存在する。 (4)弦長が短い地すべりで単位体積重量やすべり面深度 の影響を強く受ける事例では同時に土質強度定数の 影響も強く受け，両者の不確定要素に対策工効果を うち消しあうような推定誤差が生じた場合は, 効果 推定值の差異が相殺されて小さくなる。

これらの傾向は簡易Janbu法も簡便法もほぼ同じである。 以上の結果は計画安全率を地すべりの規模を考虑した 值に設定する必要があることを示唆している。特に弦長 $L$ が200m以下の小規模な地すべりの場合, 計画安全率 を1.5以上に設定しなければならない地すべりも存在する。

しかし，小規模な地すべりでも不確定要素の影響が小 さい地すべりも存在している。これは地すべりの断面形 状によるものであると考えるが法則性は見いだせていない。 規模が小さいというだけで，計画安全率をむやみに大き くするということは経費削減の趨勢に逆行するものであり， かつ合理的ではない。現時点では解析対象の地すべり断 面形状が不確定要素の影響をどの程度受けるかを安定解 析時に個別に検証し，その程度を評価した上で，計画安 全率を設定するという方法がより良い方法であると考える。 安定解析式による対策工効果推定值の差異については 簡便法による効果の推定値が簡易Janbu法より大きくな る地すべりの割合が，抑制工，抑止工共に 6 割以上で あった。この 6 割以上という比率の高さからも，また， 簡易Janbuの方が簡便法より内部応力の釣り合いなどが 考慮され，より厳密解に近いことからみても，簡便法を 用いた設計が過小設計になっている地すべりが多く存在 する可能性は高い。

\section{6. おわりに}

安定解析に関する不確定要素が対策工の効果推定に与 える影響と, 同じく安定解析式の違いが与える影響につ いて検証した結果，次のことが明らかになった。

(1)不確定要素による対策工効果推定值の差異はその頻 度分布や地すべり規模との関係が対策工毎に大きく 異なる。

(2)単位体積重量の約10\%の推定誤差に伴う排土工効果 推定値の差異は, 今回の計算条件の場合, 全体の $93 \%$ の地すべり地で $1 \%$ 以下の小さな差異に収まり，単 位体積重量の誤差が排土工効果の推定に与える影響 は小さい。
(3)地すべり縦断面の弦長 $L か ゙$ 短い地すべりほど不確定 要素による影響を受けやすい地すべりが多い。特に 弦長 $L$ が $200 \mathrm{~m}$ 以下の地すべりでは安全率の差で0.2 以上の大きな効果推定值の差異が発生する場合があ る。弦長 $L か ゙ 500 \mathrm{~m}$ 越えると不確定要素による影 響は小さくなり，今回の計算条件の範囲内では効果 推定値の差異は 0.02 程度以下であった。

(4) 1 つの不確定要素による対策工効果推定值の差異が 対策工を併用することにより増大し，安全率の差に して0.46程度の差が生じることもある（土質強度定 数の誤差が抑制工併用時に与える影響)。

(5)不確定要素の中では特にすべり面の土質強度定数の 違いが与える影響が優勢である。他の不確定要素に よる効果推定值の差異はほとんどの事例で土質強度 定数の違いによって相殺され影響が小さくなること が確認されたが，土質強度定数の影響は相殺されな い事例が数多く存在した。

66簡便法による対策工効果の推定が簡易Janbu法による ものより大きくなる地すべりが全体の 6 割以上にな り，この傾向は抑制工と抑止工で顕著な違いはない。 地下水排除工では全体の $98 \%$ の地すべり地で簡便法に よる工事効果推定の方が大きな効果として計算される。 今回の検証では 3 つの不確定要素の中ですべり面の強 度定数の影響が大きいことが確認された。すべり面の強 度定数の影響が大きいということは $c^{\prime} ， \phi^{\prime}$ 逆算時の安全 率や地下水位分布が不適切であった場合も，工事効果の 推定誤差が大きいということである。

今回の解析は全体の誤差の分布状態に着目したもので あり一定の成果は得られたが，今後は詿差の現れ方の違 いが弦長 $L$ 以外の地すべり断面形状のどこの違いによる ものかについて検証し，法則性を見いだす必要がある。 また，今回検証した不確定要素の他に，逆算時の間隙水 圧分布の違いや地すべりの移動方向と解析方向が一致し ない場合の問題, 3 次元解析と 2 次元解析の問題など, 対策工効果の推定に大きな影響を及ぼす要因はあるが, これらについては今後取りあげていく予定である。

\section{参考文献}

1）木下 恵，榎田充哉：岩盤地すべりに対するJanbu式の適用 性について，第38回地すべり学会研究発表講演集, pp. 283〜 286, 1999

2 ）榎田充战，木下 恵：地すべりの安全率に与える不確定要素 の影響について, 第39回地すべり学会研究発表講演集, pp. 313 316, 2000

3 ）社日本河川協会：建設省河川砂防技術基準(案) 同解説語画偏, pp. 85, 山海堂, 1997

4) 藤原明敏：地すべりの解析と防止対策，pp. 425〜 426, 理工 図書, 1979

5 ）山田剛二, 渡正亮, 小橋澄治：地すべり・斜面崩壊の垁態と 対策，pp. 37〜 38，山海堂， 1971

6) 申 潤植：地すべり工学一理論と奏践一, pp. 794, 山海堂, 1989

7 ）木下 恵，榎田充哉：岩盤地すべりにおけるJanbu法の優位 性と適用性，地すべり，Vol. 37，No. 3，pp. 25-31，2000 （原稿受付2001年 8 月23日，原稿受理2001年10月26日） 